Article

\title{
The Bangladesh Sustainability Compact: An Effective Tool for Promoting Workers' Rights?
}

\author{
Jeffrey S. Vogt \\ Solidarity Center, Washington, DC 20036, USA; E-Mail: jvogt@solidaritycenter.org
}

Submitted: 5 July 2017 | Accepted: 8 November 2017 | Published: 14 December 2017

\begin{abstract}
The impetus for the Bangladesh Sustainability Compact was the Rana Plaza industrial disaster, which took the lives of roughly 1,200 garment workers and injured twice. The Compact required the fulfilment of several time-bound commitments by the Bangladesh government in two key areas-labour law reform and protection of the right to freedom of association and ensuring fire and building safety. The EU heralded the Compact as an innovative, multilateral approach to encourage its trade partners to comply with ILO core labour rights. The editors of this issue of Politics and Governance asked the contributing authors to examine effectiveness of trade and labour standards and to consider alternative mechanisms to advance workers' rights. Specifically, they queried whether the Compact could be considered a new and effective alternative model. This hope appears misplaced.
\end{abstract}

\section{Keywords}

Bangladesh; Bangladesh Accord; EBA; EU; GSP; ILO; labour rights; Sustainability Compact; trade; trade union

\section{Issue}

This article is part of the issue "Labour Standards in a Global Environment", edited by Gerda Van Roozendaal (University of Groningen, The Netherlands) and Jan Orbie (Ghent University, Belgium).

(C) 2017 by the author; licensee Cogitatio (Lisbon, Portugal). This article is licensed under a Creative Commons Attribution 4.0 International License (CC BY).

\section{Introduction}

On 8 July 2013, the European Union and the government of Bangladesh, with support from the International Labour Organisation (ILO), negotiated the Bangladesh Sustainability Compact (hereinafter the 'Compact'; Directorate General for Trade, 2013). ${ }^{1}$ The impetus for the Compact was the Rana Plaza industrial disaster, which only three months earlier had killed nearly 1,200 garment workers and injured twice as many (Manik \& Yardley, 2013). Built several stories taller than permitted, the poorly constructed building collapsed when vibrations from the generators on the rooftop shook the building. For the EU, this was a crisis as several flagship European brands, which had long touted social responsibility, had imported billions of euro worth of garments from factories in Bangladesh-from Rana Plaza and many other factories just as unsafe (Clean Clothes Campaign, 2015). ${ }^{2}$

\footnotetext{
${ }^{1}$ The US and Canada joined the Sustainability Compact later.

${ }^{2}$ It provides a list of brands linked to Rana Plaza.

3 "Let's remember that none of the factories operating in Rana Plaza had trade unions" said Phil Robertson, deputy Asia director. "If their workers had more of a voice, they might have been able to resist managers who ordered them to work in the doomed building a day after large cracks appeared in it".
}

The Compact required the government of Bangladesh to fulfil several time-bound commitments, including measures to ensure fire and building safety in the readymade garment (RMG) sector and measures to protect the right to freedom of association and to bargain collectively, including labour law reform. The lack of a trade union to stand up to management, who had forced workers into the Rana Plaza building even as cracks appeared on the interior walls, was an important factor in the high death toll (Human Rights Watch, 2016). ${ }^{3}$ Further, the ILO had for years urged the government (unsuccessfully) to amend its labour laws and to enforce those already on the books. Parallel to the Compact, donor governments contributed millions of Euro for capacity building projects (ILO, 2017a).

The editors of this issue of Politics and Governance asked contributing authors to examine the effectiveness of trade and labour standards and consider alter- 
native mechanisms to advance workers' rights. Specifically, they queried whether the Compact could be considered a new and effective approach. As I argue below, the Compact has not been effective for much of its four years, though recent developments in mid-2017 might yet produce some results. For comparison, I examine another initiative which operated in Bangladesh at roughly the same time, namely the Bangladesh Accord for Fire and Building Safety (Accord), which is a private initiative between international trade unions and apparel brands. Though more limited in scope, namely to ensure fire and building safety in RMG factories sourcing to signatory brands, the Accord has produced positive results and has essentially eliminated work-related fatalities in covered factories.

\section{What is the Compact?}

Simply put, the Compact is a compliance plan negotiated under the auspices of the EU's Generalised System of Preferences' "Everything but Arms" (EBA) programme (European Parliament, 2012). The EBA is a unilateral scheme that eliminates tariffs and quotas on all goods (except arms) exported to the EU. To maintain these trade benefits, beneficiary countries must respect certain standards including not engaging in "serious and systematic" violations of the eight ILO fundamental conventions. ${ }^{4}$ In the case of "serious and systematic" violations, the EU can initiate an investigation which can lead to the suspension or withdrawal of trade preferences (European Parliament, 2012). ${ }^{5}$

At the launch of the Compact, then-EU Trade Commissioner Karel De Gucht explicitly linked the Compact to the EBA (De Gucht, 2013). ${ }^{6}$ In 2015, Trade Commissioner Cecilia Malmström indicated that the EU might reconsider its stand on the EBA if compliance with the terms of the Compact did not improve (Malmström, 2015). ${ }^{7}$ This position was reinforced most recently in 2017 in a pair of strongly-worded letters from the European Commission to the government of Bangladesh (discussed below) threatening an imminent investigation and the loss of trade preferences. ${ }^{8}$ In the end, the Compact is a specific plan as to how to comply with the EBA and draws its coercive power from the threat of EBA suspension. Govern- ments have long used trade preference programs to seek improvement on labour rights-including through checklists like the Compact (US Department of Labor, 2013). ${ }^{9}$

The Compact is monitored through an intergovernmental process, the so-called " $3+5$ Group", (the Labour, Commerce and Foreign Affairs Ministries of Bangladesh + representatives of the EU, US, Canada and two rotating EU member states) and is supported by the ILO. The Group also holds a public summit on a roughly annual basis, alternating between Brussels and Dhaka, which also allows for the participation of stakeholders, including trade unions, in the monitoring process. The most recent summit was held on 18 May 2017 in Dhaka. At the same time, there have been frequent informal communications between the EU and international trade unions between formal summits. The EU has published three technical status reports, in 2014 (European Commission, 2014), 2015 (European Commission, 2015), and 2016 (European Commission, 2016a), evaluating the government's compliance. They draw on information provided by the government and social partners including the International Trade Union Confederation (2017). Following each summit, the 3+5 Group has issued Joint Conclusions in 2015, 2016 (European Commission, 2016b) and 2017 (European Commission, 2017a) reflecting the sense of the parties, including that of the government of Bangladesh, and setting forth agreed next steps.

In making its assessment, the EU also gives great deference to the ILO supervisory system. The ILO's Committee of Experts on the Application of Conventions and Recommendations has published increasingly critical reports related to the issues covered by the Compact, in particular ILO Conventions 87 (freedom of association) and 98 (collective bargaining) (ILO, 2017b). For several consecutive years, Bangladesh's compliance with ILO Convention 87 has also been the subject of supervision by the ILO's Conference Committee on the Application of Standards (CAS), a tripartite body which gives follow-up recommendations to the annual reports of the ILO Committee of Experts (ILO, 2017b). In 2016, the CAS was so concerned with the government's failure to apply Convention 87 that it put its conclusions on Bangladesh in a "special paragraph" of the Committee's report to the International Labour Conference (ILO, 2016a). This

\footnotetext{
${ }^{4}$ For a list of those conventions, see http://www.ilo.org/global/standards/introduction-to-international-labour-standards/conventions-and-recommend ations/lang--en/index.htm

5 Under Article 19, trade preferences can be withdrawn for "serious and systematic violation of principles laid down in the conventions listed in Part A of Annex VIII". These conventions include the eight ILO core conventions, including the right to freedom of association and to bargain collectively.

6 “Bangladesh also enjoys an extremely favourable trade regime under the EU's 'Everything but Arms' initiative. This is of particular importance for readymade garments, which represent about 90 percent of Bangladesh's exports to the EU. These enter the EU market with no restriction: duty-free and quota-free. These exports to the EU account for about 2.5 million jobs-mostly for women. 'Everything but Arms' is therefore a major contributor to job and income generation for millions of people in Bangladesh. I want to make it clear that Bangladesh-or for that matter any other Least Developed Country-cannot take for granted the trade preferences it currently enjoys" (De Gucht, 2013).

7 "But the future of the garment industry depends not just on the price of its products but also on its reputation with consumers. And that reputation will simply not survive another disaster like this. Another tragedy, or even just a continuation of today's poor conditions for workers, could also force the European Union to revisit Everything but Arms. It remains, after all, conditional on respect for fundamental labour rights" (Malmström, 2015).

${ }^{8}$ Although other key market actors like the US and Canada participate in the Compact's supervisory process, the leverage is held entirely held by the EU and is derived from the potential loss of the EBA. The US already suspended GSP to Bangladesh in 2013 (described below), losing much of its economic leverage. Canada does not condition its GSP on compliance with labour rights and is in any case a very small consumer market compared to the EU and the US.

${ }^{9}$ See indeed, in 2013 the US developed a checklist for Bangladesh to regain GSP benefits, which it suspended after Rana Plaza.
} 
is meant to signal a serious failure on the part of a government to apply a ratified convention (ILO, 2011). An ILO High Level Tripartite Mission also visited the country in April 2016, and issued a highly critical report on the violations of freedom of association, thus corroborating the allegations made by the trade unions (ILO, 2016b). These reports were incorporated into the EU's technical status reports to the extent that they touched on issues relevant to the Compact.

\section{What Has the Compact Accomplished?}

Respect for labour rights in Bangladesh has remained extremely low, except for an all-too-brief period immediately following the Rana Plaza disaster when global scrutiny on the country's labour practices was at its most intense. However, after the immediate shock wore off, global apparel brands purchased goods from their Bangladeshi suppliers at record rates (Matsangou, 2016). The government quickly came to realise that the industry would face no economic consequences for its bad behaviour and thus recommenced its repression of workers (by act or omission). Below, I highlight some of the key issues which the government of Bangladesh was required to address under the Compact. In every case, the government failed to deliver as required.

\subsection{Implementation and Enforcement of Labour Law}

The Compact required that the government implement and enforce its labour laws. ${ }^{10}$ Two critical implementation issues have been consistently raised-the failure of the government to register unions and the failure of the government to investigate or sanction employers who engage in anti-union discrimination. These two areas were specifically identified elsewhere in the Compact as a prerequisite for establishing the ILO's Better Work programme. ${ }^{11}$

\subsection{Refusal to Register Unions}

For many years, the government had implemented a nounion policy in the RMG sector. Workers who sought to register unions often saw the founders sacked and the registration processes drag on without end. Immediately following the Rana Plaza disaster, the government felt significant pressure, from governments, unions and brands, to reverse its no-union policy. In late 2013 and 2014, new unions were formed and successfully registered, though collective bargaining was still opposed. However, by early 2015, the government again routinely rejected registration applications. From 2010-2017, half of all applications for union registration were denied. Of 860 total applications, 424 were granted and 417 were

\footnotetext{
${ }^{10}$ Compact, Section $1 \mathrm{~b}$.

11 Compact, Section $1 \mathrm{f}$.

12 The data has been compiled by the Solidarity Centre and is available upon request.

13 The data has been compiled by the Solidarity Centre and is available upon request.

14 This information has been conveyed to the Solidarity Centre by affected unions.
}

rejected-the bulk of the rejections coming in 2015$2016 .^{12}$ The number of registration applications also dropped precipitously from the peak in 2014 (392) to 2016 (130), as anti-union discrimination continued and intensified with impunity. ${ }^{13}$ Some unions, namely those that had been the most successful in organising workers, have been told by the authorities not to bother applying as their applications would be rejected. ${ }^{14}$

The reasons for the rejections are often completely fabricated and have no basis in the regulations. In other cases, applications were rejected even after unions corrected them per the government's instructions. As explained in the section below, public officials are poorly resourced and are under considerable pressure from the garment industry, which has significant influence over the government, to keep the industry union-free. The 2016 ILO High Level Mission report noted that the procedure for registering unions "had the likelihood of discouraging trade union registration" (ILO, 2016b, para. 43). In 2017, the ILO Committee of Experts called on the government "to take any necessary measures to ensure that the registration process is a simple formality, which should not restrict the right of workers to establish organizations without previous authorization" (ILO, 2017c). The European Commission also noted that "that there has been a marked increase in rejections of registration requests and a decrease in registration of trade unions over the last months" (ILO, 2016a).

In 2017, the government adopted standard operating procedures (SOPs) for union registration. The SOPs do provide timelines for registration and indicate who is responsible at each step of the registration process. However, the SOPs fail to address the many barriers workers face in the registration process and, without effective mechanisms in place to sanction Joint Directorate of Labour staff when applications are arbitrarily denied, unions in Bangladesh expect this behaviour to continue.

For example, in March 2017, workers at Savar Factory and Orchid Garment, both owned by the powerful Azim Group, had their application for union registration rejected for the third time. The reasons given were vague, likely indicating the political influence of the Azim Group. Indeed, Mr. Azim was himself a member of Parliament. Workers at both factories had been organizing with the Bangladesh Independent Garment Union Federation (BIGUF) since early 2016. In May 2017, thugs attacked union leaders and nearly 70 workers from Orchid Sweaters outside of the factory gate (IndustriALL Global Union, 2017a).

\subsection{Anti-Union Discrimination}

The leaders of many of the unions registered post-2013 have suffered retaliation, sometimes violent, by manage- 
ment or their agents. Some union leaders were brutally beaten and hospitalized (Human Rights Watch, 2015; see also Human Rights Watch, 2014). Entire executive boards have been sacked. In some cases, the police, at the apparent behest of factory management, have intimidated and harassed trade unionists (Human Rights Watch, 2015). The responses by the labour inspectorate have been very slow to date. Most union leaders or members illegally fired for trade union activity have not been reinstated and most employers have not been punished for these egregious violations. In cases of anti-union violence, police routinely fail to carry out credible investigations, if at all. In the few cases where workers have been reinstated, it was the result of an international campaign to pressure brands, not because of labour inspection and enforcement by the government (Greenhouse \& Tabuchi, 2015). This of course is not a reliable or sustainable model to enforce the law.

The ILO High Level Tripartite Mission Report "noted with concern the numerous allegations of anti-union discrimination and harassment of workers" as well as "blacklisting, transfers, arrests, detention, threats and false criminal charges" (ILO, 2016b). In 2017, the Committee of Experts also expressed "concern" regarding the reports "alleging numerous instances of anti-union discrimination, slowness of the labour inspectorate in responding to such allegations and the lack of adequate sanctions in practice, as well as a serious lack of commitment to the rule of law" (ILO, 2017D). The EU also urged the government "to address these reports without delay and notably by taking the necessary steps to ensure the effective investigation and prosecution of these cases, by ensuring reinstatement of those illegally dismissed and by imposing fines or criminal sanctions according to the law" (European Commission, 2016a).

\subsection{Implementing Rules}

The Compact has required Bangladesh to pass implementing regulations to the Bangladesh Labour Act, which had just been amended in 2013 (Government of Bangladesh, EU, \& ILO, 2013). In late 2015, two years past due, the government did issue the regulations. However, many of its provisions violate ILO Convention 87 . For example, employers are given a role in the election committee of worker representatives to factorylevel Worker Participation Committees. Where there is no union, which is the case in the vast majority of workplaces, Worker Participation Committees determine who is on the Safety Committees. If a worker vacancy opens on the Safety Committee, employers also have a role in determining who should replace the worker representative. The probability of management domination of these committees is high, and there does not appear to be a clear and dissuasive sanction for such acts of interference. Given the centrality of safety concerns in the post-Rana Plaza period, the failure of the new rules to en- sure that Safety Committees are independent of management and thus free to identify and protest unsafe working conditions creates the potential for future safety and health disasters.

The ILO concurred, urging the government "to undertake any necessary measures to ensure that, under the Bangladesh Labour Rules, workers' organizations are neither restricted nor subject to interference in the exercise of their activities and internal affairs, that unfair labour practices are effectively prevented and that all workers, without distinction whatsoever, may participate in the election of representatives (ILO, 2016c). The EU also echoed these concerns (ILO, 2016a). As yet, the government has not taken any action to address this issue.

\subsection{Labour Law Reform}

The government of Bangladesh did pass modest reforms to the Bangladesh Labour Act in 2013, which were in motion well before the Compact was negotiated (Government of Bangladesh et al., 2013). However, the Compact also obligated Bangladesh to undertake further reforms (Government of Bangladesh et al., 2013); the government failed to address nearly all the observations of the ILO Committee of Experts in the 2013 reforms, and in some cases made the law even less compliant with ILO Conventions. As a result, the Committee of Experts stated that it "deeply regrets" the failure to amend the labour law and "urges the government, in consultation with the social partners, to review and amend the mentioned provisions to ensure that restrictions on the exercise of the right to freedom of association are in conformity with the Convention" (ILO, 2016c). The 2016 report of the EU reached the same conclusion (European Commission, 2016a).

\subsection{Freedom of Association in Export Processing Zones (EPZs)}

EPZs employ roughly 400,000 workers in Bangladesh, who produce garments and footwear as well as a variety of other manufactured goods (European Commission, 2016a). However, trade unions are banned in the EPZs by law and only Worker Welfare Associations may be established under the EPZ Workers' Association and Industrial Relations Act (EWWAIRA) of 2010. The Worker Welfare Associations do not have the same rights and privileges as trade unions. However, the government had steadfastly refused to change the law to allow unions, citing promises made to investors years ago to keep the zones union free. ${ }^{15}$ In 2017, the ILO Committee of Experts called on the government "to ensure that any new legislation for the EPZs allows for full freedom of association, including the right to form free and independent trade unions and to associate with the organizations of their own choosing, and emphasizing the desirability of a harmonization of the labour law throughout the country"

\footnotetext{
15 This assertion has been made on numerous occasions to the author by Bangladesh officials.
} 
(ILO, 2016c). The European Commission similarly concluded that, "The Bangladesh EPZ Labour Act needs to be revised to provide rights and protections at least commensurate with the national labour law $(B L A)$ and to be fully compliant with core labour rights" (European Commission, 2016a).

\subsection{Upgrading Labour Inspection}

The Compact required that the government significantly improves its labour inspection (Government of Bangladesh et al., 2013). While the government did upgrade the Department of the Chief Inspector of Factories and Establishments to a Directorate, it has still failed to ensure it has a cadre of 800 inspectors as agreed in the Compact. Beyond the numbers, labour inspectors have a profound lack of training and professionalism which severely weaken the effectiveness of factory inspections. This is further undermined by the power of the industry over the government, which does not want to see the law enforced. In a 2017 interview with ILO Dhaka staff, they indicated that they believed that the government was still several years away from having a factory inspection service that could ensure building safety as well as enforce fundamental labour rights. The EU concluded in its most recent report that "recruitment and training of inspectors need to continue in view of reaching the target of 800 inspectors....The recruitment and the development of a strategy for the retention of new labour inspectors needs to be taken as matter of urgency" (European Commission, 2016a).

\subsection{Fire and Building Safety}

Section 2 of the Compact sets forth the government's commitments on fire and building safety. Under Section 2(a), the government committed to make concrete and time-bound improvements under the National Tripartite Plan of Action focused on Occupational Health and Safety, specifically Fire and Building Safety. This included providing access to remedies for victims of workplace injuries. However, implementation of the plan has been very slow and most if not all milestones in the plan have been missed or substantially delayed. The absence of a consolidated public and transparent reporting of progress under the Plan contributes to the lack of accountability.

The inspection of export-oriented RMG factories under Section 2(b) was divided among the two private initiatives (the Bangladesh Accord and the Alliance for Bangladesh) and the national effort under the National Action Plan. While both private initiatives completed initial inspections in 2014, the National Initiative finished an initial inspection of the factories far behind schedule.
In its last status report, the Department of Inspection for Factories and Establishments indicated that 300 Corrective Action Plans (CAP) have been developed in factories under the national initiative but only 5 CAPs have been approved. Of concern, this information has not been updated in over a year, as the information is from March 2016. There is no public database of the actual inspections or CAPs (Department of Inspection for Factories and Establishments, 2016). Therefore, progress on implementation is difficult to assess in the absence of a publicly available database for the CAPs under the National Initiative.

There is very little evidence that the crucial remediation efforts under the national initiative are in process, and the financing of the remediation measures of the factories under the national effort is unclear. Recently, the ILO highlighted the need for financing to support remediation in Bangladeshi factories, which underscored the absence of a strategy to ensure the factories under the national initiative have the necessary financial support for remediation.

\section{Why Has the Compact Failed (2013-2016)?}

There is no single explanation for the failure of the Compact. Below, I explore some of the contributing factors.

\subsection{The Government of Bangladesh}

The government of Bangladesh has and will likely continue to be hostile to labour rights. First and foremost, the garment industry is responsible for 82 percent of the country's export earnings (World Bank, 2017). Thus, anything that would in the government's view "jeopardize" the profitability and continuity of the industry, including trade unions, is perceived as an existential threat and dealt with accordingly. Of course, trade unions can contribute to a more productive and sustainable industry (Freeman \& Medoff, 1984; see also OECD, 2000), ${ }^{16}$ and respect for labour rights does not put countries at a competitive disadvantage in world trade (OECD, 1996). ${ }^{17}$ Nevertheless, the government and domestic manufacturers have opted to avoid unions at all costs (except when forced to do so by union organising supported by global campaigns).

Another factor, Bangladesh has failed to upgrade the industry-unlike many of its competitors. Bangladesh's success in garment exports has been based on lowskill, low-wage competitiveness. The severe lack of adequate transportation and energy infrastructure has hampered the industry's growth. As the World Bank found, "Private investors are discouraged from investing in Bangladesh because of infrastructure deficits, scarcity and high prices of land, corruption, political uncertainty

\footnotetext{
$\overline{16}$ "Countries which strengthen their core labor standards can increase efficiency by raising skill levels in the workforce and by creating an environment which encourages innovation and higher productivity" (OECD, 2000).

17 "Any fear on the part of developing countries that better core standards would negatively affect either their economic performance or their competitive position in world markets has no economic rationale" (OECD, 1996).
} 
and, of late, concerns about security. Severe scarcity of gas and electricity is making the process of getting utility connections for new businesses difficult (World Bank, 2016)". Given these weaknesses, the government has not moved up the value chain to higher value added goods. As such, it continues to see its advantage in competing on the basis of low labour costs - which would be threatened if a truly robust labour movement were allowed to form.

Third, the government is plagued by high levels of public corruption and is subject to corporate capture by the garment industry (McDevitt, 2015). ${ }^{18}$ As explained in the New York Times, "Business interests dominate Bangladesh's Parliament. Of its 300 members, an estimated 60 percent are involved in industry or business. Analysts say 31 members, or 10 percent of the country's national legislators, directly own garment factories, while others have indirect financial interests in the industry" (Yardley, 2013; see also Chalmers, 2013). ${ }^{19}$ The Bangladesh Garment Manufacturer's Association (BGMEA) is extremely powerful, and is a key contributor to political campaigns (Yardley, 2013). ${ }^{20}$ As a result, legislation consistent with international labour standards is unlikely to pass without overwhelming external pressure, and agencies charged with enforcement have no incentive to do so.

Finally, Bangladesh's garment industry has yet to experience an economic penalty from the Rana Plaza disaster. Only one buyer, Walt Disney, pulled out of Bangladesh following the collapse (Greenhouse, 2013). In fact, garment orders increased, ironically the likely result of the negotiation of the Bangladesh Accord for Workers' Safety, which required signatory brands to ensure that its suppliers provided safe working environments (Reuters, 2015). As discussed below, over 200 companies eventually supported the Accord (Accord on Fire and Building Safety in Bangladesh, 2017a). With the Accord in place, brands calculated that the risk of sourcing from Bangladesh had dropped to an acceptable level. Indeed, the success of the Accord has demonstrated that respect for workers' rights, or at least the avoidance of workplace injuries or fatalities, is good for business. With the manufacturers prospering, the government has had no incentive to change course.

Neither the government nor the industry has paid a penalty for its aggressive anti-unionism. Both understood that they could ignore the Compact without consequences for its trade relationship with the EU.

\subsection{The EU}

Despite growing concerns, the European Commission remained extremely reluctant through 2016 to commence an investigation (European Parliament, 2015, para. 25). ${ }^{21}$ This is in part due to a deep-seated faith of the EU institutions in European social dialogue, which favours cajoling over measures to compel another party to act or to sanction that party for inaction. Even after years of broken promises, the EU was not moved to threaten an investigation leading to the withdrawal of preferences until early 2017 (as explained in Section 5).

Another basis for the reluctance is that the levy of duties on imports of Bangladesh-made garments would mean that EU-based companies would suddenly face substantially higher costs for its goods. As confirmed in informal conversations in Brussels, the EU's Trade Commissioner has been reminded of this fact by European brands.

At a more technical level, the European Commission's institutional reluctance is compounded by a misguided interpretation of its own GSP Regulation (Vogt, 2015). The Directorate General for Trade of the European Commission (DG Trade) has determined that the trigger for the commencement of an investigation is two consecutive "special paragraphs" in the reports of the CAS. This approach reflects a fundamental misunderstanding of the ILO supervisory system and all but guarantees EU inaction. The CAS is the more political body within the ILO supervisory system and a decision to issue a special paragraph requires the consent of both worker and employer representatives-the latter of whom are often very reluctant to do so. Bangladesh did receive a special paragraph from the CAS in 2016, aided by the fact that the employer spokesperson had participated in the High Level Tripartite Mission earlier that year and had seen how bad the situation was only weeks before the International Labour Conference. However, the employers group flatly refused to agree to a special paragraph in 2017, despite the lack of progress, because they knew it would trigger an investigation. Thus, in adopting this peculiar interpretation of the GSP regulation, the EU has essentially delegated decision-making to a small, unelected body of employers in a single supervisory committee of the ILO (Vogt, 2015). Though it is not certain that the government of Bangladesh would improve compliance with fundamental workers' rights were a GSP investigation to be commenced, the loss of preferential access to the EU

\footnotetext{
18 "Politics in Bangladesh can be characterised as a battle between established elites over state resources. A culture of confrontational politics between the country's two main parties has weakened the rule of law and led to the politicisation of state institutions, including the judiciary and bureaucracy. At the same time, political parties and parliament are increasingly being taken over by powerful business interests. Thus, despite a relatively strong legal framework, weak implementation and political interference undermine anti-corruption efforts in Bangladesh. As a result, corruption is an endemic problem in Bangladesh at all levels of society" (McDevitt, 2015).

19 "More than 30 garment industry bosses are members of parliament, accounting for about 10 percent of its lawmakers" (Chalmers, 2013).

20 "'This organization [BGMEA] is extremely powerful', said one senior government official, who said much of its clout comes from political contributions. 'The political parties are running after money'” (Yardley, 2013).

21 The European Parliament has been less circumspect and has called on the Commission to determine whether Bangladesh is complying with the GSP conditionality in 2015. In late 2016 and early 2017, members of the International Trade Committee of the European Parliament visited Bangladesh and warned the government that the EU is running out of patience.
} 
garment market-14.8 billion euros in 2016 (European Commission, 2017b)-would seem to be a very considerable incentive.

\subsection{The US}

In 2013, immediately following the Rana Plaza collapse, the US suspended its GSP benefits to Bangladesh in response to a 2007 petition by the AFL-CIO concerning widespread labour violations, including violations of the right to freedom of association, to bargain collectively and to eliminate child labour (Greenhouse, 2016). An action plan based on an investigation into the complaint and seven years of dialogue failed to bring about meaningful reforms (US Department of Labor, 2013). For the US, the Rana Plaza disaster was the last straw, confirming years of indifference for workers' rights and well-being. The suspension did get the attention of the government of Bangladesh as it was a negative signal to the market. Bilateral engagement on labour issues did increase as a result. However, as Bangladesh's garment exports did not benefit under the US GSP scheme (unlike the EU), the impact of the suspension was minimal in economic terms. In the end, with the Bangladesh Accord in place, and a secure market in the EU, the suspension of the US GSP was not sufficient leverage for change and most violations continued apace after 2013. While the US does participate in the oversight of the Compact, its economic leverage over Bangladesh is reduced given that it has little more it can do to sanction poor performance on labour rights.

\subsection{The Global Brands}

The Rana Plaza disaster, and the continued failure of manufacturers in Bangladesh to respect fundamental workers' rights, is a structural feature of global supply chains as currently configured-particularly in the garment industry. Brands look to cut costs in their supply chains through several means, from negotiating down the costs of the goods they source to, maximizing efficiency and reducing tax and other expenses. At the same time, brands look to turn product orders around quickly to respond to expectations of consumers-so called fast fashion. This puts considerable pressure on manufacturers to drive down wages and benefits, push for excessive overtime, and cut corners on working conditions. This also creates a situation where unionization will cut into small margins, especially at lower tier manufacturers, and thus unions are opposed by any means (ILO, 2016d, paras. 60-64).
At the same time, Rana Plaza exposed the failure of the CSR initiatives and social auditing to detect and remedy violations of workers' rights in global supply chains. While these schemes have sometimes been able to identify workplace violations such as wage and hour and occupational safety and health issues, they have generally failed to detect violations that are not readily apparent, such as violations of the right to freedom of association and to bargain collectively (ILO, 2016d, para. 138; see also Locke, 2013, p. 20). ${ }^{22}$ Social auditors are generally not adequately trained and do not spend adequate time to detect any but the most obvious violations (ILO, 2016d, para. 138). Brands have also failed to adopt sufficient measures to identify which companies are even producing goods in their supply chains, particularly beyond the Tier I suppliers. If steps are not taken to clearly map their suppliers, it will be impossible to ensure brands' compliance with human rights policies.

\section{Potential for Progress in 2017?}

On 16 March 2017, in a break with the typical diplomatic language, three senior European Commission officials sent a strongly worded letter to the Ambassador of Bangladesh to the EU. It explained:

We will need to demonstrate to the European Parliament, Council of Ministers and to civil society that Bangladesh is taking concrete and lasting measures to ensure the respect of labour rights. This will be essential for Bangladesh to remain eligible for the EBA regime. Without such progress, our monitoring could eventually lead to the launching of a formal investigation, which could result in temporary withdrawal of preferences. (Newage, 2017)

The letter followed a staggering display of anti-union animus by the government of Bangladesh. Starting on 11 December 2016, garment workers launched a peaceful demonstration for higher wages in Ashulia, an area near the capital city of Dhaka (see Kaman, 2016). ${ }^{23}$ The minimum wage for garment workers remains a mere 5,300 taka per month (roughly \$67 USD), an amount below the World Bank poverty line (Fair Labor Association, 2016, p. 3). ${ }^{24}$ and neighbouring garment-producing nations like Cambodia. ${ }^{25}$ Police rounded up at least 34 union leaders and activists, many of whom were not even in Ashulia at the time. The government subsequently lodged criminal charges against them and manufacturers subsequently filed claims alleging property damage (Human Rights

22 "Private compliance programs appear largely unable to deliver on their promise of sustained improvements in labor standards in the new centers of global production" (Locke, 2013).

${ }^{23}$ The epicentre of the strike was at Windy Apparels Ltd in Ashulia, where workers began to demand a rise in wages. The strike was ignited two months after a young woman worker died on the factory floor after repeatedly being denied medical leave by her supervisor. Her body was simply discarded by management on the street outside the factory gates for her family to pick up. An account of her tragic death at 23 years old was reported in Slate (Kaman, 2016).

24 "The FLA found that for factories assessed in Bangladesh the purchasing power of average compensation-a measure that includes base pay, and some benefits and incentives, but excludes overtime-fell below the World Bank poverty line" (Fair Labor Association, 2016).

25 Through strikes and demonstrations, the minimum wage in the garment industry in Cambodia rose in recent years from \$60 USD in 2013 to \$170 USD per month in 2018. 
Watch, 2017). BGMEA organised factory managers to suspend, dismiss or force to resign well over 1,600 workers in a coordinated closure of roughly 60 garment factories (Human Rights Watch, 2017; see also Safi, 2016). Police raided the offices of several trade unions and labour rights NGOs, disrupting their activities and forcing their doors closed.

On 18 May 2017, the 3+5 Group convened in Dhaka to formally review the government's progress under the Compact and to raise concerns about the recent crackdown in Ashulia. Just prior to the summit, the government withdrew a 2016 draft EPZ labour law, which would have maintained the prohibition on trade unions in the zones (Bdnews24, 2017). The government also signalled a commitment to adopt a new EPZ labour law, though it has yet to follow through.

The "Joint Conclusions" of the summit committed the government to comply with the original terms of the Compact as well as to respect the post-Ashulia agreement (European Commission, 2017a). In another letter, issued on 31 May 2017 the European Commission again took a firm position. ${ }^{26}$ It explained that:

Much more needs to be done to address the ILO's recommendations on freedom of association and collective bargaining ahead of the $106^{\text {th }}$ Session of the International Labour Conference on 7 June 2017. The EU is concerned that so far no reply has been given to its letter of 16 March and that no strategy with concrete and time bound actions has been presented at the Compact meeting, in order to address the ILO's recommendations, as was requested in the letter.

The EU gave the government a deadline of the end of August "to deliver tangible progress". The letter concluded by explaining that:

With regard to the preferences granted to Bangladesh under the EU's GSP Regulation, we would like to recall that Bangladesh needs demonstrate as a matter of urgency concrete and lasting measures are taken to ensure respect of fundamental human and labour rights. This will be essential for Bangladesh to remain eligible for the Everything but Arms regime.

At the International Labour Conference, Bangladesh was again hauled before the CAS for its failure to comply with Convention 87 (ILO, 2016e). In that session, it announced its commitment to amend both the Bangladesh Labour Act and the EPZ Labour Act in 2017. It also reported on having adopted the new SOPs for union registration. For the first time, the government appears to perceive a measurable economic risk to maintaining the status quo. As of this writing, however, the government has initiated a process to review the Bangladesh Labour Act, but has not circulated any drafts for comment by the social partners. It is far too early to know whether the government intends to address the concerns of the ILO Committee of Experts and will expend the political capital to see them passed. Further, there is no data to ascertain whether the SOPs have made any difference concerning registration. As in the BIGUF case cited above, applications for union registration continue to be rejected arbitrarily despite the new procedures.

It remains to be seen whether the EU will overcome its institutional reluctance if there is still insufficient progress made in the coming months. As of this writing, DG Trade remains steadfast in its opposition to commencing an investigation. ${ }^{27}$ If that position continues, one can expect that the government of Bangladesh will undertake the minimum to forestall the threat of a GSP investigation.

\section{New Compliance Mechanisms}

It was common knowledge among the global brands that most factories in Bangladesh were poorly constructed, had faulty wiring, lacked fire exits and that doors were often locked; however, the cost of providing a safe workplace was deemed too expensive for brands and thus no action was taken (Greenhouse, 2012). ${ }^{28}$ The Rana Plaza disaster also exposed a deep crisis in the code of conduct and audit model, given that garment factories in Rana Plaza and elsewhere had been certified despite unsafe working conditions or repeated violations of fundamental worker rights (see Section 4 above). This crisis created the opportunity for a new model-the Bangladesh Accord for Fire and Building Safety and Better Work Bangladesh. Notably, a similar proposal had been presented to brands before the Rana Plaza disaster given the outbreak of deadly fires like Tazreen Fashions (Bajaj, 2012), but only two brands expressed any interest. The Accord was negotiated in the days immediately following Rana Plaza, as global brands panicked knowing that significant action needed to be taken if they were to be able to maintain their sourcing relationships in Bangladesh. In the end, over 200 brands, mostly European, signed on to the Accord.

The Accord signals an important break with past models in that it is a legally binding instrument among brands, retailers and trade unions to ensure the safety of the factories where the signatory brands source their goods (Anner, Bair, \& Blasi, 2013). The Accord carries out independent inspections in which unions and workers are involved. All the inspection reports and corrective plans are publicly disclosed. Brands also had to commit that if a factory was unable to remediate based on the corrective plans, that the brand would ensure that funds

\footnotetext{
26 Letter on file with the author.

27 Based on a call between the author and DG Trade on 10 July 2017.

28 The article reports on a 2011 meeting of government, manufacturers, brands and NGOs during which the director of ethical sourcing from Walmart rejected proposed improvements in electrical and fire safety. They noted that such improvements would need to be made to around 4,500 factories, would be "very extensive" and "not financially feasible" (Greenhouse, 2012).
} 
were available to do so. A complaints mechanism was created and workers were instructed on the right to refuse unsafe work. According to its 8 May 2017 report: "The overall remediation progress rate of safety issues identified in initial inspections reported or verified as fixed has reached 77 percent. Remediation is close to completion at more than 400 Accord Factories which have completed more than $90 \%$ of the remediation. 61 factories have completed all remediation from initial inspections" (Accord on Fire and Building Safety in Bangladesh, 2017b, p. 4). In 71 cases, the Accord terminated supplier relationships with brands because of the failure of the factory to meet the safety standards set out in the agreement (Accord on Fire and Building Safety in Bangladesh, 2017b, p. 12).

The success of the Accord comes from the fact that it can terminate sourcing relationships between brands and suppliers when the latter do not live up to the fire and building safety requirements. This is significant economic leverage over a factory, which the Accord has used when warranted by the evidence. The inclusion of workers in the governance of the Accord, as well as the plant level inspection, also certainly improves the quality of the labour inspection. Most importantly, the Accord has succeeded in eliminating worker deaths in the factories it covers (with the exception of a boiler explosion in 2017; Accord on Fire and Building Safety in Bangladesh, 2017c), an impressive feat given that there were over 1,350 deaths in the garment sector just between 2010 and $2013 .^{29}$

The Accord also helped to empower workers. Safety training had been rare and workers had no role in safety management. Joint worker-management safety committees were established in factories covered by the Accord, and workers on the committees were trained on their rights and best practices. All workers were provided basic information about their rights ensure their safety at work. As of May 2017, over a million workers have received information about their rights (Accord on Fire and Building Safety in Bangladesh, 2017d, p. 15).

On 29 June 2017, the Accord was renewed (Accord on Fire and Building Safety in Bangladesh, 2017e). One important advancement with the new Accord is that it requires factories to respect the freedom of association of workers as it relates to safety and health (Accord on Fire and Building Safety in Bangladesh, 2017e). It is unclear how many of the brands under the original Accord will sign the new one, though nearly 50 brands signed on as of October 2017 (IndustriALL Global Union, 2017b).

The Accord has not been without its critics, which have argued that the Accord (and the Alliance for Bangladesh Worker Safety) cover only a small portion of the RMG sector leaving workers in many factories, particularly those in the subcontracted factories that do not directly export, outside the scope of these initiatives (Labowitz \& Baumann-Pauly, 2015; but see Anner \& Bair, 2016). ${ }^{30}$ It is certainly true that not all workers are covered by the Accord. It is also true that not all manufacturers have made the necessary remedial steps to comply with the Accord. And, some brands have been taken to arbitration for failure to cover the costs of remediation. However, this should not diminish the progress made by the Accord, and limitations in the scope of commitments or coverage reflects more the reluctance of brands to move further than an inherent flaw with the Accord model.

The government of Bangladesh and the BGMEA, which have long resented their exclusion from the governance of the Accord, announced the launch of a parallel initiative. While details are not yet available, one suspects that it will be less onerous and accountable given that the government and BGMEA will have a say in its operation, likely joined by government dominated trade unions (Ullah Mirdha, 2017). As mentioned above, the inspections which were under the purview of the government under the National Action Plan were flawed and incomplete, and the lack of transparency make impossible the ability to assess what corrective measures, if any, have been taken. Of note, global unions and the government reached an agreement in late October on the eventual phase out the 2018 Accord. Under its terms, a committee comprised of industry, labour and the ILO will, after May 2018, determine every six months whether the government has achieved the capacity to monitor the industry and enforce the law effectively. If such a determination is made, responsibility for fire and building safety would revert to a national body after a further 6 months (IndustriALL Global Union, 2017c).

It should also be noted that Better Work Bangladesh, a joint program of the ILO and the World Bank, is now also operational in the country. Better Work has a broader mandate, in that it assesses conditions on fundamental labour rights as well as conditions of work, from wage and hour laws to occupational safety and health. ${ }^{31}$ Currently it is monitoring 136 factories in Dhaka which supply to roughly 30 brands. In addition to these assessments, Better Work works with factories to provide advice and training to management to assist them to make continuous improvements. Better Work publishes synthesis reports which note which violations have been detected and which have been remediated after followup. The incentive for factories to participate include the higher productivity that will result from better labourmanagement relations and the reduction in the number

\footnotetext{
29 This figure includes the reported estimated death tolls at Gharib and Gharib (2010, 21), Hameem Group (2010, 29), Tazreen Fashions (2012, 112), Smart Exports $(2013,8)$, Rana Plaza $(2013,1135)$ and Tung Hai Sweater $(2013,8)$.

${ }^{30}$ Report arguing that the Accord and the Alliance cover "only $27 \%$ of factories, which tend to be larger and better resourced than all other factories" amounting to about half the workforce. A rebuttal report was issued in 2016. See Rebuttal report arguing that "more than $70 \%$ of garment workers in Bangladesh are covered by the Accord and the Alliance, and if we include workers employed in factories inspected by the ILO-advised National Initiative, the percentage of covered workers reaches $89 \%$ ".

${ }^{31}$ For more information, visit the Better Work Bangladesh website at https://betterwork.org/where-we-work/bangladesh
} 
of audits as brands will accept Better Work assessments without requiring their own. As Better Work is still relatively new to Bangladesh, it has yet to publish its first synthesis report.

\section{Conclusion}

For workers in Bangladesh's garment industry, the situation remains dire. Worker rights violations are the norm and safety concerns are especially serious outside of Accord-covered factories. At the same time, Bangladesh remains a global powerhouse for garment production and continues to export worldwide. Indeed, the repression has ensured that labour costs remain among the lowest in Asia. The only thing in recent years that created sufficient pressure on the government and industry to reform was the Rana Plaza disaster, and even then, the reform on workers' rights was partial and fleeting. It is clear that unless there is a substantial economic incentive to change, for the government, for manufacturers and for global brands, we will not see the necessary changes take place. Clearly, the Compact has not provided an incentive, as no credible threat of economic harm was ever posed. On the other hand, we have seen trade unions and brands at the very least create the legal framework necessary to promote the limited issue of the safety of garment factories. Whether this is replicable elsewhere remains to be seen, as it took a tremendous tragedy for brands to agree to the Accord in the first place.

\section{Conflict of Interests}

The author declares no conflict of interests.

\section{References}

Accord on Fire and Building Safety in Bangladesh. (2017a). Signatories. ACCORD. Retrieved from http:// bangladeshaccord.org/\%20signatories

Accord on Fire and Building Safety in Bangladesh. (2017b, May 8). Quarterly aggregate report on remediation progress at RMG factories covered by the Accord statistics as of April. Retrieved from http:// bangladeshaccord.org/wp-content/uploads/AccordQuarterly-Aggregate-Report-May-2017.pdf

Accord on Fire and Building Safety in Bangladesh. (2017c, July 5). Accord statement on boiler explosion at Multifabs Ltd. [Press release]. Retrieved from http://bangladeshaccord.org/2017/07/accordstatement-boiler-explosion-multifabs-Itd

Accord on Fire and Building Safety in Bangladesh. (2017d, August 23). Quarterly aggregate report on remediation progress at RMG factories covered by the Accord statistics as of July 1st, 2017. Retrieved from http:// bangladeshaccord.org/wp-content/uploads/AccordQuarterly-Aggregate-Report-August-2017.pdf

Accord on Fire and Building Safety in Bangladesh. (2017e, June 29). Press release New accord 2018
[Press release]. Retrieved from http://bangladesh accord.org/2017/06/press-release-new-accord-2018

Anner, M., \& Bair, J. (2016, February 10). The bulk of the iceberg: A critique of the Stern Center's report on worker safety in Bangladesh. Penn State Center for Global Workers Rights. Retrieved from http://Iser.la. psu.edu/gwr/documents/CGWRCritiqueofSternRe port.pdf

Anner, M., Bair, J., \& Blasi, J. (2013). Toward joint liability in global supply chains: Addressing the root causes of labor violations in international subcontracting networks. Comparative Labor Law \& Policy Journal, 35(1), 1-43.

Bajaj, V. (2012, November 25). Fatal fire in Bangladesh highlights the dangers facing garment workers. The New York Times. Retrieved from http://www.nytimes. com/2012/11/26/world/asia/bangladesh-fire-killsmore-than-100-and-injures-many.html?mcubz=0

Bdnews24. (2017, May 19). Sustainability Compact review sets new priorities for Bangladesh apparel sector. Bdnews24. Retrieved from https://bdnews24. com/business/2017/05/19/sustainability-compactreview-sets-new-priorities-for-bangladesh-apparelsector

Chalmers, J. (2013, May 3). Special report: How textile kings weave a hold on Bangladesh. Reuters. Retrieved from https://www.reuters.com/article/usbangladesh-garments-special-report/special-reporthow-textile-kings-weave-a-hold-on-bangladesh-idUS BRE9411CX20130502

Clean Clothes Campaign. (2015). Clean clothes campaign. Retrieved from https://cleanclothes.org/ safety/ranaplaza/who-needs-to-pay-up

De Gucht, K. (2013, July 8). Remarks by EU Trade Commissioner Karel De Gucht on the launch of a global Sustainability Compact in response to Bangladesh tragedies [Press release]. Retrieved from http://eur opa.eu/rapid/press-release_MEMO-13-670_en.htm

Department of Inspection for Factories and Establishments. (2016, March 16). Status of building safety assessments-16 March 2016. Department of Inspection for Factories and Establishments. Retrieved from http://database.dife.gov.bd

Directorate General for Trade. (2013, July 8). Staying engaged: A Sustainability Compact for continuous improvements in labour rights and factory safety in the ready-made garment and knitwear industry in Bangladesh. Retrieved from http://trade.ec.europa. eu/doclib/docs/2013/july/tradoc_151601.pdf

European Commission. (2014, July 8). Staying engagedA Sustainability Compact for continuous improvements in labour rights and factory safety in the readymade garment and knitwear industry in Bangladesh (Technical Progress Report 8 July 2014). Brussels: European Commission.

European Commission. (2015, April 24). Bangladesh Sustainability Compact (Technical Status Report 24 April 2015). Brussels: European Commission. 
European Commission. (2016a, July). Bangladesh Sustainability Compact (Technical Status Report July 2016). Brussels: European Commission.

European Commission. (2016b). Joint conclusions second follow-up meeting on Bangladesh Sustainability Compact Dhaka. Brussels: European Commission.

European Commission. (2017a). Joint conclusions: Third follow-up meeting on the Sustainability Compact. Retrieved from http://trade.ec.europa.eu/ doclib/docs/2017/may/tradoc_155599.pdf

European Commission. (2017b). European Union, trade in goods with Bangladesh. Brussels: European Commission.

European Parliament. (2012, October 25). Regulation (EU) No 978/2012 of the European Parliament and of the Council of 25 October 2012 applying a scheme of generalised tariff preferences and repealing Council Regulation (EC) No 732/2008 (Official Journal of the European Union No. L 303/1). Strasbourg: European Parliament. Retrieved from http://eur-lex. europa.eu/legal-content/EN/ALL/?uri=CELEX:32012 R0978

European Parliament. (2015, April 28). Resolution on the second anniversary of the Rana Plaza building collapse and progress of the Bangladesh Sustainability Compact. Strasbourg: European Parliament.

Fair Labor Association. (2016, August). Toward fair compensation in global supply chains: Factory pay assessments in 21 countries. Washington, DC: Fair Labor Association.

Freeman, R., \& Medoff, J. (1984). What do unions do? New York, NY: Basic Books

Government of Bangladesh, European Union, \& International Labour Organization. (2013, July 8). Joint statement: Staying engaged: A Sustainability Compact for continuous improvements in labour rights and factory safety in the ready-made garment and knitwear industry in Bangladesh. Retrieved from http://trade.ec.europa.eu/doclib/docs/2013/july/tra doc_151601.pdf

Greenhouse, S. (2012, December 5). Documents indicate Walmart blocked safety push in Bangladesh. The New York Times. Retrieved from http://www.nytimes.com /2012/12/06/world/asia/3-walmart-suppliers-madegoods-in-bangladeshi-factory-where-112-died-in-fire. html

Greenhouse, S. (2013, May 1). Some retailers rethink role in Bangladesh. The New York Times. Retrieved from http://www.nytimes.com/2013/05/02/business/so me-retailers-rethink-their-role-in-bangladesh.html

Greenhouse, S. (2016, June 27). Obama to suspend trade privileges with Bangladesh. The New York Times. Retrieved from http://www.nytimes.com/2013/06/28/ business/us-to-suspend-trade-privileges-with-bang ladesh-officials-say.html

Greenhouse, S., \& Tabuchi, H. (2015, February 8). Company in Bangladesh agrees to union peace. The New York Times. Retrieved from https://www.nytimes. com/2015/02/19/business/international/azim-bang ladeshi-factory-agrees-to-union-peace-to-win-backcustomers.html?mtrref=undefined \&gwh $=47544351$ B586F8E62FE975B5F818AD42\&gwt=pay

Human Rights Watch. (2014, February 6). Bangladesh: Protect Garment workers' rights. Human Rights Watch. Retrieved from https://www.hrw.org/news/ 2014/02/06/bangladesh-protect-garment-workersrights

Human Rights Watch. (2015, April 22). "Whoever raises their head suffers the most": Workers' rights in Bangladesh's garment factories. Human Rights Watch. Retrieved from https://www.hrw.org/report/ 2015/04/22/whoever-raises-their-head-suffers-most /workers-rights-bangladeshs-garment\#2acc2e

Human Rights Watch. (2016, April 21). Bangladesh: Garment workers' union rights bleak. Human Rights Watch. Retrieved from https://www.hrw.org/news/ 2016/04/21/bangladesh-garment-workers-union-ri ghts-bleak

Human Rights Watch. (2017, February 15). Bangladesh: Stop persecuting unions, garment workers: Brands should make binding commitments to protect freedom of association. Human Rights Watch. Retrieved from https://www.hrw.org/news/2017/02/15/bang ladesh-stop-persecuting-unions-garment-workers

IndustriALL Global Union. (2017a). Attempts to form unions met with violence in Bangladesh [Press release]. Retrieved from http://www.industriall-union. org/attempts-to-form-unions-met-with-violence-inbangladesh

IndustriALL Global Union. (2017b). Global unions urge more brands to sign new Bangladesh Accord [Press release]. Retrieved from http://www.industriallunion.org/global-unions-urge-more-brands-to-signnew-bangladesh-accord

IndustriALL Global Union. (2017c). Process agreed to prepare for future handover of Bangladesh Accord to a national regulator [Press release]. Retrieved from http://www.industriall-union.org/process-agreed-toprepare-for-future-handover-of-bangladesh-accordto-a-national-regulator

International Labour Organization. (2011). The Committee on the Application of Standards of the International Labour Conference. Retrieved from http:// www.oit.org/wcmsp5/groups/public/---ed_norm/--normes/documents/publication/wcms_154192.pdf

International Labour Organization. (2016a). Third item on the agenda: Information and reports on the application of Conventions and Recommendations (Report of the Committee on the Application of Standards). Geneva: International Labour Organization.

International Labour Organization. (2016b). Report of the high-level tripartite mission to Bangladesh. Geneva: International Labour Organization.

International Labour Organization. (2016c). Observation (CEACR)-Adopted 2016, published 106th ILC session (2017). International Labour Organization. 
Retrieved from http://www.ilo.org/dyn/normlex/en/ $f ? p=1000: 13100: 0:: N O: 13100: P 13100 \_C O M M E N T$ _ ID:3297151

International Labour Organization. (2016d). Decent work in global supply chains (Report IV). Geneva: International Labour Organization.

International Labour Organization. (2016e). Report of the Committee on the Application of Standards (Provisional Record Part II, 106th Session). Geneva: International Labour Organization. Retrieved from http://www.ilo.org/wcmsp5/groups/public/--ed_norm/---relconf/documents/meetingdocument/ wcms_489124.pdf

International Labour Organization. (2017a). Projects. International Labour Organization. Retrieved from http://www.ilo.org/dhaka/Whatwedo/Projects/lang-en/index.htm

International Labour Organization. (2017b). NORMLEX information system on international labour standards, country profiles, Bangladesh. International Labour Organization. Retrieved from http://www. ilo.org/dyn/normlex/en/f?p=NORMLEXPUB:11110:0 ::NO::P11110_COUNTRY_ID:103500

International Labour Organization. (2017c). Observation (CEACR)-Adopted 2016, published 106th ILC session (2017). International Labour Organization. Retrieved from http://www.ilo.org/dyn/normlex/en/ $\mathrm{f}$ p $=$ NORMLEXPUB:13100:0::NO::P13100_COMMENT ID:3297151

International Labour Organization. (2017d). Observation (CEACR)-Adopted 2016, published 106th ILC session (2017). International Labour Organization. Retrieved from http://www.ilo.org/dyn/normlex/ en/f?p=1000:\%2013100:0::NO:13100:P13100_COM MENT_ID:3297191

International Trade Union Confederation. (2017). Bangladesh Sustainability Compact @ 4: Situation is worsening, time for action is now. Retrieved from http://www.industriall-union.org/sites/default/files/ uploads/documents/2017/BANGLADESH/the_failure _of_the_bangladesh_sustainability_compact_2017. pdf

Kaman, A. (2016, December 15). We are nothing but machines to them. Slate. Retrieved from http:// slate.me/2k1DtWI.

Labowitz, S., \& Baumann-Pauly, D. (2015, December). Beyond the tip of the iceberg: Bangladesh's forgotten apparel workers. NYU Stern Center for Business and Human Rights. Retrieved from http://people. stern.nyu.edu/twadhwa/bangladesh/downloads/be yond_the_tip_of_the_iceberg_report.pdf

Locke, R. (2013). The promise and limits of private power: Promoting labor standards in a global economy. New York, NY: Cambridge University Press.

Malmström, C. (2015, April 22). Remembering Rana Plaza: what next? Speech of Trade Commissioner Cecilia Malmström at the conference: Remembering Rana Plaza, Brussels. Retrieved from http://trade.ec. europa.eu/doclib/docs/2015/april/tradoc_153350. pdf

Manik, J. A., \& Yardley, J. (2013, April 24). Building collapse in Bangladesh leaves scores dead. The New York Times. Retrieved from http://www.nytimes.com/ 2013/04/25/world/asia/bangladesh-building-collapse. html

Matsangou, E. (2016, January 26). Bangladesh textile industry sets export record, record exports for Bangladesh amid growing demand for cheap clothing. World Finance. Retrieved from https://www.world finance.com/markets/bangladesh-textiles-industryset-global-export-record

McDevitt, A. (2015, June 17). Overview of corruption and anti-corruption in Bangladesh. Transparency International. Retrieved from https://www.transparency. org/whatwedo/answer/overview_of_corruption_and _anti_corruption_in_bangladesh1

Newage. (2017, March 24). EC warns Bangladesh of GSP suspension. Newage. Retrieved from http://www.newagebd.net/article/11897/ec-warnsbangladesh-of-gsp-suspension

OECD. (1996). Trade, employment and labor standards, a study of core workers' rights and international trade. Paris: OECD.

OECD. (2000, October). International trade and core labour standards (Policy Brief). Paris: OECD. Retrieved from https://www.oecd.org/tad/1917944.pdf

Reuters. (2015, July 7). Bangladesh exports up 3.4 pct in 2014/15 as garment sales surge. Reuters. Retrieved from https://www.reuters.com/article/bangladeshexports/bangladesh-exports-up-3-4-pct-in-2014-15as-garment-sales-surge-idUSL3N0ZN2B820150707

Safi, M. (2016, December 27). Bangladesh garment factories sack hundreds after pay protests. The Guardian. Retrieved from https://www.theguardian.com/ world/2016/dec/27/bangladesh-garment-factoriessack-hundreds-after-pay-protests

Ullah Mirdha, R. (2017, August 17). BGMEA plans to form platform like Accord, Alliance. The Daily Star. Retrieved from http://www.thedailystar.net/ business/bgmea-plans-form-platform-accord-alliance $-1449859$

United States Department of Labor. (2013, July 19). Statement by the U.S. government on labor rights and factory safety in Bangladesh [News release]. Retrieved from https://www.dol.gov/opa/media/ press/ilab/ILAB20131494.htm

Vogt, J. (2015, September). A little less conversation: The EU and the (non) application of labour conditionality in the generalized system of preferences. International Journal of Comparative Labour Law and Industrial Relations, 31(3), 285-304.

World Bank. (2016). Bangladesh development update, October 2016: Sustained development progress (Report). Washington, DC: World Bank. Retrieved from https://openknowledge.worldbank.org/handle/1098 $6 / 25274$ 
World Bank. (2017, June 1). World Bank helps Bangladesh diversify exports and create 90,000 new jobs [Press release]. Retrieved from http://www. worldbank.org/en/news/press-release/2017/06/01/ world-bank-helps-bangladesh-diversify-exports-and- create-90000-new-jobs

Yardley, J. (2013, July 24). Garment trade wields power in Bangladesh. The New York Times. Retrieved from http://www.nytimes.com/2013/07/25/world/asia/ garment-trade-wields-power-in-bangladesh.html

\section{About the Author}

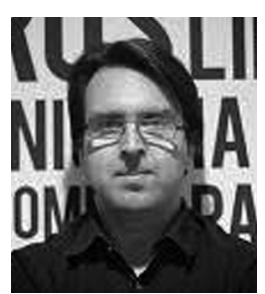

Jeffrey S. Vogt is the Legal Director of the Solidarity Center, where he coordinates the organization's legal advocacy before international institutions, advises trade unions on labor law and policy, and assists in litigation before national and international tribunals. From 2011 through 2016, Vogt was legal director of the International Trade Union Confederation (ITUC). Before joining the ITUC in 2011, he served as AFL-CIO deputy international department director and also was AFL-CIO global economic policy specialist. He is a graduate of Cornell Law School, where he earned his J.D. and L.L.M. in international and comparative law. 